\title{
Temperature Regulates the Initiation of Chasmothecia in Powdery Mildew of Strawberry
}

\author{
Belachew Asalf, David M. Gadoury, Anne Marte Tronsmo, Robert C. Seem, Lance Cadle-Davidson, \\ Marin Talbot Brewer, and Arne Stensvand
}

First and third authors: Department of Plant and Environmental Sciences, Norwegian University of Life Sciences, 1432 Ås, Norway; first and seventh authors: Norwegian Institute for Agricultural and Environmental Research (Bioforsk), Plant Health and Plant Protection Division, 1432 Ås, Norway; second and fourth authors: Department of Plant Pathology, Cornell University, New York State Agricultural Experiment Station, Geneva, New York 14456; fifth author: United States Department of Agriculture-Agricultural Research Service, Grape Genetics Research Unit, Geneva, NY 14456; sixth author: Department of Plant Pathology, University of Georgia, Athens 30602. Accepted for publication 29 January 2013.

\section{ABSTRACT}

Aslaf, B., Gadoury, D. M., Tronsmo, A. M., Seem, R. C., Cadle-Davidson, L., Brewer, M. T., and Stensvand, A. 2013. Temperature regulates the initiation of chasmothecia in powdery mildew of strawberry. Phytopathology 103:717-724.

The formation of chasmothecia by the strawberry powdery mildew pathogen (Podosphaera aphanis) is widespread but often sporadic throughout the range of strawberry cultivation. In some production regions, notably in warmer climates, chasmothecia are reportedly rare. We confirmed that the pathogen is heterothallic, and that initiation of chasmothecia is not only dependent upon the presence of isolates of both mating types but also largely suppressed at temperatures $>13^{\circ} \mathrm{C}$. Compared with incubation at a constant temperature of $25^{\circ} \mathrm{C}$, progressively more chasmothecia were initiated when temperatures were decreased to $13^{\circ} \mathrm{C}$ for progressively longer times. At lower temperatures, production of chasmothecia was associated with a decline in but not total cessation of conidial formation, and pairings of compatible isolates sporulated abundantly at $25^{\circ} \mathrm{C}$. We developed mating-type markers specific to $P$. aphanis and used these to confirm the presence of both mating types in populations that had not yet initiated chasmothecia. The geographic discontinuity of chasmothecia production and the sporadic and seemingly unpredictable appearance of chasmothecia in $P$. aphanis are possibly due to the combined influence of heterothallism and suppression of chasmothecia formation by high temperatures.

Additional keywords: Fragaria $\times$ ananassa, Sphaerotheca macularis.
Powdery mildew is a destructive disease of cultivated strawberry (Fragaria $\times$ ananassa Duch.). The pathogen Podosphaera aphanis (Wallr.) U. Braun \& S. Takam. (syn. Sphaerotheca macularis, $P$. macularis) occurs throughout the range of strawberry cultivation (24). The asexual state was first reported on strawberry plants in the United Kingdom by Berkeley in 1854 (7,28), while the sexual state was first reported by Arthur in the United States in 1888 (7). Chasmothecia were long assumed to be nonfunctional structures $(1,14,24,27)$, and their role in perpetuating the disease has only recently been demonstrated (9).

Chasmothecia of $P$. aphanis have been considered rare in some regions $(7,14,28)$, despite the frequent occurrence of the asexual state of the pathogen $(1,7,24,28)$. In Norway, the asexual state was reported and found to cause severe damage on susceptible cultivars in 1910 (19) but the sexual state was not reported until 1945 (20). Chasmothecia were first reported in the United Kingdom in 1960 (21); Ontario, Canada in 1959 (16); Nova Scotia, Canada in 1978 (13); and Florida in 1981 (14). Amsalem et al. (1) were unable to find the sexual state of $P$. aphanis during four consecutive years of study in Israel. The mechanisms responsible for the temporal and geographic discontinuity of formation of the sexual state of this widely distributed pathogen were unknown. Occurrence of chasmothecia of $P$. aphanis does seem to be less

Corresponding author: B. Asalf; E-mail address: belachew.asalf.tadesse@umb.no or belachew.asalf.tadesse@ bioforsk.no

* The $\boldsymbol{e}$-Xtra logo stands for "electronic extra" and indicates that Figure 4 appears in color online.

http://dx.doi.org/10.1094/PHYTO-09-12-0252-R

(c) 2013 The American Phytopathological Society common in warmer climates (1) but whether this reflects a climatic effect, the absence of compatible mating types within a heterothallic population, or an artifact of annual strawberry production systems is also unclear.

Environmental cues can affect whether powdery mildews reproduce sexually or asexually (29). The relationship between environmental factors, in particular temperature, and the asexual stages (conidial germination and conidiation) of $P$. aphanis is well known $(1,17,18,28)$ but there is a lack of quantitative information on how environmental factors affect sexual reproduction. Heterothallism (11), host resistance (29), variation between day and night temperatures, senescence of host tissue (16), high temperature (15), mycoparasitism (26), starvation of the pathogen, and short photoperiods have all been suggested as stimulatory or suppressive to initiation or development of chasmothecia in various powdery mildews (30).

We reported previously that $P$. aphanis is heterothallic (9). Thus, a geographically discontinuous distribution of mating types might provide one possible explanation for the absence or rare occurrence of the sexual state of $P$. aphanis in some areas. Sexually compatible isolates of powdery mildew fungi can be distinguished by results of pairings on susceptible plant tissue but this is laborious and time consuming. Applying primers specific to MAT1-1 and MAT1-2 in a single polymerase chain reaction (PCR) has allowed the identification of mating types in Erysiphe necator (Schwein.) (5), and development of similar technology for $P$. aphanis would provide a more expedient means to investigate the possible involvement of mating-type distribution as a factor in the occurrence of the sexual state.

The objectives of this study were to (i) determine whether variation in numbers of chasmothecia produced in various pair- 
ings of compatible isolates exists, (ii) investigate whether a suppressive effect of increasing temperature upon chasmothecia formation provides a plausible explanation of their rarity in warmer climates, (iii) evaluate the depth and duration of lowertemperature exposure required to stimulate formation of chasmothecia, and (iv) develop a PCR-based marker for mating-type in $P$. aphanis. Preliminary accounts of this work have been published (2).

\section{MATERIALS AND METHODS}

Collection and maintenance of $\boldsymbol{P}$. aphanis isolates. Immature trifoliate leaves (light green, leaflets slightly separated from each other, lamina unfolded $\approx 5^{\circ}$ ) of 'Korona' strawberry were used for maintenance of isolates and experimental work. To keep plants free of powdery mildew prior to inoculation, plants were treated daily with sulfur for 3 to $4 \mathrm{~h}$ at night from a sulfur vaporizer (BBK Veksthus, Tønsberg, Norway). Absence of powdery mildew immediately prior to inoculation was confirmed by examining leaves under a dissection microscope at $\times 10$ to $\times 80$.

Trifoliate leaves were surface sterilized in sodium hypochlorite $(0.5 \%)$ and rinsed in distilled water three times; then, the water was allowed to dry from the leaf surface by placing the leaves on blotting paper. After drying, the petiole was removed and the lamina were divided into single leaflets, unfolded gently, and placed into petri dishes containing water agar $(0.5 \%$ agar amended with $0.03 \%$ benzimidazole), with the adaxial (upper) surface of the leaflets facing the agar surface (3). Leaflets were randomized among the petri dishes to randomize effects of leaf age variation among treatments. Thus, petri dishes contained three leaflets originating from three different leaves.

Monoconidial isolates of $P$. aphanis were prepared as follows. Leaves bearing mildew colonies were collected from commercial plantings at eight different locations in southern Norway in June and July 2008 (Table 1). Conidia were transferred with a paint brush to detached leaflets in petri dishes as previously described. In addition, collected leaves that had few conidia were first incubated at $20^{\circ} \mathrm{C}, 80 \%$ relative humidity $(\mathrm{RH})$, and a 16-h daily light period to stimulate conidiation. Once sporulation had occurred, single conidia were transferred to new leaflets in petri dishes with water agar from each source using an eyelash or thin copper wire, as described by Gadoury and Pearson (11). Each selected conidium was placed on a leaflet in a separate petri dish and incubated at $20^{\circ} \mathrm{C}$ and $80 \% \mathrm{RH}$ for 7 days. Thereafter, a leaflet bearing a sporulating colony was selected for each collection site, and subculturing as above was repeated to ensure that it was clonal. Monoconidial isolates were transferred to new leaves every 8 to 10 days by gently touching the leaflet bearing the monoconidial isolate to the abaxial (lower) leaf surface of Korona in petri dishes with water agar, and incubated as previously described.
Compatibility of isolates and production of chasmothecia among compatible pairs. Eight monoconidial isolates collected from eight locations from southern Norway were paired in all 36 possible combinations (Table 1) to determine mating type. On each inoculated leaflet, isolates were paired on opposite sides of the midvein, $\approx 5 \mathrm{~mm}$ apart, and were incubated at $13^{\circ} \mathrm{C}, 80 \% \mathrm{RH}$, and $16 \mathrm{~h}$ of day light. Beginning 1 week after inoculation, leaflets were observed for the formation of chasmothecia. Presence or absence of chasmothecia was assessed using a dissecting microscope at $\times 40$ magnification. For all pairings in which chasmothecia were found, the percentage of the leaflets bearing chasmothecia was recorded. For 15 pairings forming chasmothecia, the number formed on each leaflet 3 weeks after inoculation was assessed using a dissecting microscope at $\times 63$, and chasmothecial density per square centimeter of leaflet area was estimated. There were three replicates for each pair of isolates (three leaflets, each from different leaves, per replicate), and the experiment was conducted twice.

Effects of temperature on initiation of chasmothecia. Two isolate pairings (Sola and Hamar or Sola and Ringsaker) that produced abundant chasmothecia in the above experiment were selected to determine the effects of temperature on initiation of chasmothecia. Detached leaflets on water agar in petri dishes were inoculated with paired isolates as above, and then incubated at $13,15,20$, or $25^{\circ} \mathrm{C}, 80 \% \mathrm{RH}$, and a 16-h daily light period. The different developmental stages of the chasmothecia (white, brown, and black) were distinguished and counted under a dissecting microscope as described above. There were three replicates for each isolate pairing and treatment (three leaflets, each from different leaves, per replicate), and the experiment was conducted twice.

A similar experiment was performed on potted strawberry plants, with the following modifications. Forty-eight plug plants of Korona were supplied from a certified plant propagator, potted in $10-\mathrm{cm}$ plastic pots filled with peat on 5 July 2009, and maintained at $20^{\circ} \mathrm{C}$ in a greenhouse for 5 weeks. While at $20^{\circ} \mathrm{C}$, powdery mildew was observed on the plants, which may have come from the nursery and spread naturally. The plants were incubated at $9,12,15$, and $18^{\circ} \mathrm{C}, 80 \% \mathrm{RH}$, and a 12-h daily light period on 10 August 2009 in a phytotron. On 15 September, 30 mildewed leaves were removed from the plants at each temperature and the presence of chasmothecia was determined under a dissecting microscope. Each treatment had three replicates (four plants per replicate), and the experiment was conducted once.

Effect of duration of low-temperature exposure in the diurnal cycle on chasmothecia formation. The following experiments were conducted at Cornell University's Agricultural Experiment Station in Geneva, NY from August to October 2010. Two sexually compatible monoconidial isolates were established as described above from local sources in New York, and were maintained in isolation using detached leaves of 'Earliglow' and

TABLE 1. Compatibility of Podosphaera aphanis isolates and incidence of inoculated strawberry 'Korona' leaflets bearing chasmothecia incubated at $13^{\circ} \mathrm{C}$

\begin{tabular}{|c|c|c|c|c|c|c|c|c|}
\hline \multirow[b]{2}{*}{ Isolates (code) $)^{\mathrm{a}}$} & \multicolumn{8}{|c|}{ Incidence of chasmothecia ${ }^{b}$} \\
\hline & Holmestrand & Lier2 & Aas & Hamar & Lier1 & Ringsaker & Larvik & Sola \\
\hline Sola & - & - & - & $+(100)$ & $+(83)$ & $+(83)$ & - & - \\
\hline Larvik & - & - & - & $+(61)$ & $+(50)$ & $+(83)$ & - & $\ldots$ \\
\hline Ringsaker & $+(67)$ & $+(83)$ & $+(50)$ & - & - & - & $\ldots$ & $\ldots$ \\
\hline Lier1 & $+(50)$ & $+(50)$ & $+(28)$ & - & - & $\ldots$ & $\ldots$ & $\ldots$ \\
\hline Hamar & $+(50)$ & $+(67)$ & $+(50)$ & - & $\ldots$ & $\ldots$ & $\ldots$ & $\ldots$ \\
\hline Aas & - & - & - & $\ldots$ & $\ldots$ & $\ldots$ & $\ldots$ & $\ldots$ \\
\hline Lier2 & - & - & $\ldots$ & $\ldots$ & $\ldots$ & $\ldots$ & $\ldots$ & $\ldots$ \\
\hline Holmestrand & - & $\ldots$ & $\ldots$ & $\ldots$ & $\ldots$ & $\ldots$ & $\ldots$ & $\ldots$ \\
\hline
\end{tabular}

a Names of isolates represent the location name (municipal area) where they were collected in Norway.

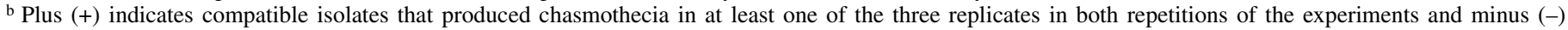
indicates that no chasmothecia were observed within the experimental periods. Values in parentheses indicate the percentage of leaflets $(n=18)$ inoculated with compatible isolates that produced chasmothecia before the end of the experiment ( 3 weeks after inoculation). 
'Elan' on water agar in petri dishes. The isolates were paired as before on opposite side of the midvein of detached Earliglow leaflets on water agar, and were subjected to one of the following treatments: (i) constant day and night temperature at $25^{\circ} \mathrm{C}$, (ii) constant day and night temperature at $13^{\circ} \mathrm{C}$, (iii) alternate high and low temperatures of $25^{\circ} \mathrm{C}$ for $23 \mathrm{~h}$ and $13^{\circ} \mathrm{C}$ for $1 \mathrm{~h}$ during the night, and (iv) alternate high and low temperatures of $25^{\circ} \mathrm{C}$ for $20 \mathrm{~h}$ and $13^{\circ} \mathrm{C}$ for $4 \mathrm{~h}$ during the night. The number of chasmothecia produced per leaflet was assessed 2 weeks after inoculation. The treatments were replicated five times (three leaflets, each from different leaves, per replicate), and the experiment was conducted twice. After assessment of treatment responses, selected leaf samples bearing chasmothecia in various stages of development were fixed in glutaraldehyde, post-fixed in osmium tetraoxide, critical-point dried, and prepared for scanning electron microscopy (SEM) as described by Gadoury et al. (10).

Effect of chasmothecia formation on conidiation. The two compatible monoconidial isolates described above were grown separately and as paired isolates to determine the impact of chasmothecia initiation and development upon asexual reproduction and productivity of conidiation. Detached leaflets of Earliglow placed on water agar were inoculated with either a monoconidial isolate or with both isolates on opposite sides of the leaflet midvein, as described above. Leaflets were incubated for $24 \mathrm{~h}$ at $18^{\circ} \mathrm{C}$ to allow uniform germination and colonization, and then incubated at $13^{\circ} \mathrm{C}$ to promote chasmothecia initiation. When chasmothecium initials were observed on leaflets inoculated with both isolates, these leaflets and leaflets inoculated with each of the single isolates and their pair were moved to $18^{\circ} \mathrm{C}$ to promote further conidiation. Once chasmothecial initials were observed on leaflets inoculated with compatible pairs of isolates, conidia were removed by washing the leaflets in $20 \mathrm{ml}$ of sterile water containing $0.05 \%$ Tween 20 , the rinse water was collected, the number of conidia contained in a 5- $\mu$ l sample on a glass microscope slide at $\times 100$ magnification was assessed, and the total number of conidia produced per leaflet was calculated. Surface water was allowed to evaporate from the leaflets, which were then returned to their respective petri dishes and further incubated at $18^{\circ} \mathrm{C}$ to promote resporulation. Two days later, the number of conidiophores at the densest area of colonization bearing one or more conidia per $\times 35$ field of view was recorded under a dissecting microscope. Each leaflet was then washed again, as above, in $20 \mathrm{ml}$ of distilled water with $0.05 \%$ Tween 20 , and the number of conidia produced per leaflet was again determined as described above. Surface water was again allowed to evaporate, the leaflets were incubated for another 4 days at $18^{\circ} \mathrm{C}$, and the foregoing assessments of conidiophores and conidiation were repeated. Treatments were replicated five times.

Determination of mating-type phenotype and genotype. Seven monoconidial isolates obtained from local sources in Geneva, NY (designated A, B, C, D, E, F, and G) were paired with an eighth isolate (designated isolate $\mathrm{H}$ ) to determine their sexual compatibility. Six of the isolates (four of one mating type and two of the other) were selected for genotyping. Genomic DNA was extracted from these isolates as described for $E$. necator (4), with the following modifications. Isolates were propagated on detached leaves of Earliglow on water agar for 8 to 10 days at $18^{\circ} \mathrm{C}$; then, conidia, conidiophores, and mycelium were collected by touching $1-$ to $2-\mathrm{cm}$ pieces of Scotch tape to the colony multiple times, until the tape was coated with a layer of fungal biomass. The tape was placed in 1.5-ml microcentrifuge tubes and stored at $-20^{\circ} \mathrm{C}$ overnight; then, $150 \mu \mathrm{l}$ of $5 \%$ chelex 100 (31) and $10 \mathrm{mg}$ of glass beads were added to each microcentrifuge tube, and each tube was vortexed for $20 \mathrm{~s}$. The tubes were then opened and the tape was submerged beneath the surface of the chelex 100 solution with a sterile wooden stick, vortexed for an additional $20 \mathrm{~s}$, centrifuged briefly, incubated at $95^{\circ} \mathrm{C}$ for $15 \mathrm{~min}$ in a heat block, vortexed for $10 \mathrm{~s}$, and incubated (at $95^{\circ} \mathrm{C}$ ) for another $15 \mathrm{~min}$. The tube was allowed to cool for $30 \mathrm{~min}$ at room temperature, and the supernatant was removed and used as the DNA template for PCR (4).

To PCR amplify the conserved $\alpha$-box region of a gene definitive of the MAT1-1 mating type in P. aphanis, we designed primers based on the $P$. xanthii sequence. The primers were the Px $\alpha$-10f: 5'-AATTCATGGATTGGCTTCAGA-3' and Px $\alpha-156$ r: 5'-GGATCACGGTTCCACAATTT-3' primers. The conserved HMG domain region of a gene that characterizes the MAT1-2 mating type was amplified by the degenerate primers: pmHMGdF 5'-CCTCCSAAYTCTTGGATTTTATAKCG-3' and pmHMGdR 5'-CGTTTAACTTCRGAAGRYTTCCGTGG-3' (5).

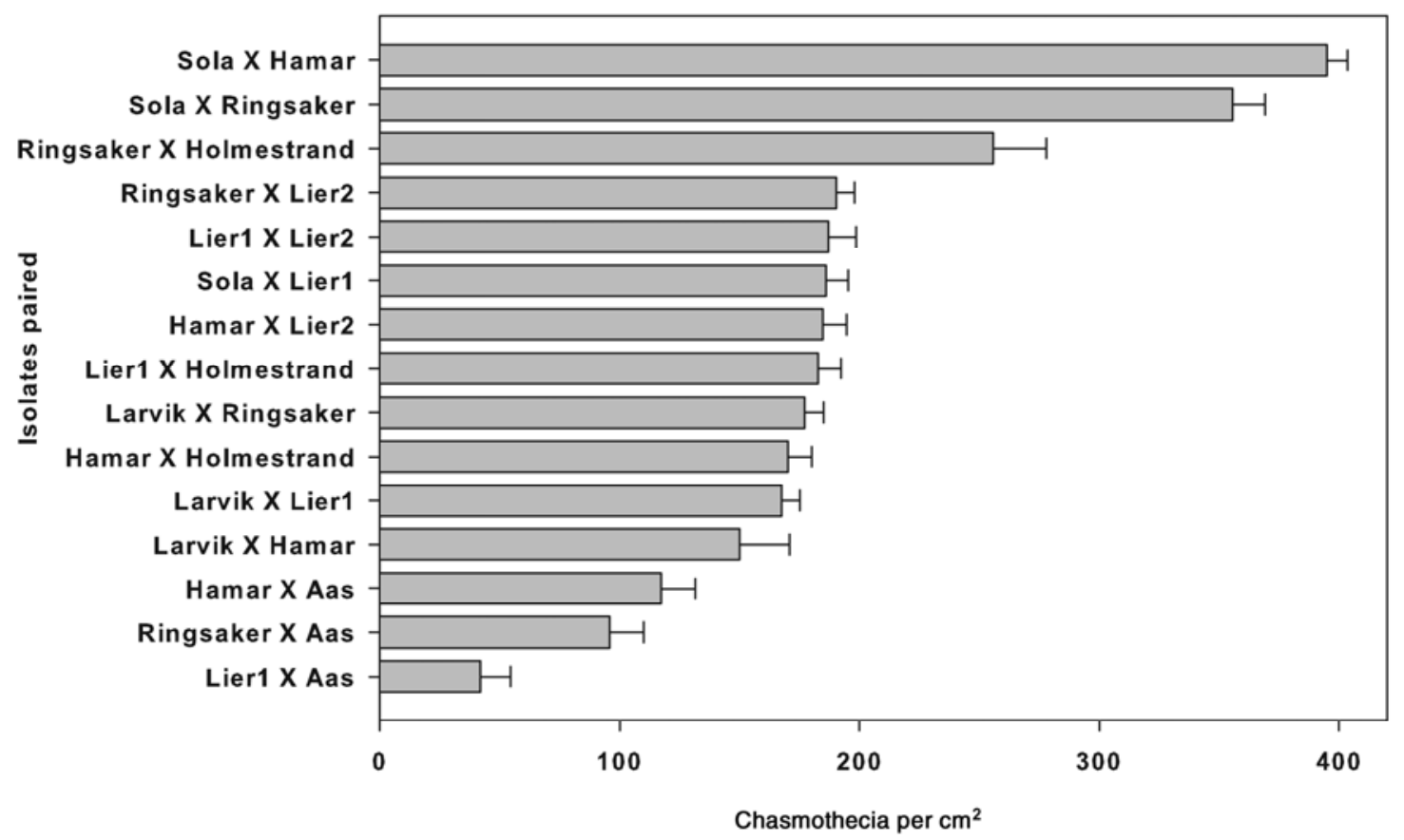

Fig. 1. Numbers of chasmothecia produced per unit of area on strawberry 'Korona' leaflets inoculated with pairs of sexually compatible isolates and incubated for 3 weeks at $13^{\circ} \mathrm{C}$. Error bars denote standard error of the mean. 
PCR and thermal cycler conditions were as previously described (5). The PCR was carried out in a $25-\mu \mathrm{l}$ volume containing $2.5 \mu \mathrm{l}$ of $10 \times$ PCR buffer, $2.5 \mu \mathrm{l}$ of dNTPs, $1.25 \mu \mathrm{l}$ of $10 \mu \mathrm{M}$ forward and $1.25 \mu \mathrm{l}$ of $10 \mu \mathrm{M}$ reverse primers, $0.75 \mathrm{U}$ of ExTaq (Takara Bio, Inc., Otsu, Japan), $1 \mu$ of DNA template, and $15.75 \mu$ of double-distilled water. Thermal cycler conditions were initial denaturation at $95^{\circ} \mathrm{C}$ for 2 min; followed by 3 cycles of $95^{\circ} \mathrm{C}$ for $1 \mathrm{~min}, 42^{\circ} \mathrm{C}$ for $1 \mathrm{~min}$, and $72^{\circ} \mathrm{C}$ for $30 \mathrm{~s}$; followed by 35 cycles of $95^{\circ} \mathrm{C}$ for $1 \mathrm{~min}, 52^{\circ} \mathrm{C}$ for $1 \mathrm{~min}$, and $72^{\circ} \mathrm{C}$ for $30 \mathrm{~s}$; followed by a final extension at $72^{\circ} \mathrm{C}$ for $5 \mathrm{~min}$. The PCR products were separated by electrophoresis in a $1 \%$ agarose gel. The DNA band of the expected length was excised and directly sequenced at the Cornell University Life Sciences Core Laboratories Center.

Development of multiplex PCR-based mating type markers. After confirming the target sequences of the $\alpha$-box and HMG domain, primers were designed specifically to the $P$. aphanis sequences, and genotypes were called for each of the isolates based on multiplex PCR amplicon size. The primers designed to amplify the $\alpha$-box region of MAT1-1 were pmoF: 5'-GGCTTCAGAAG TATGTCTCAATCAA-3' and pm $\alpha \mathrm{R}: 5^{\prime}$-TTCCACAATTTCGT CAGAAGAG- $3^{\prime}$, and the primers designed to amplify the HMG domain region of MAT1-2 were pmHMGF: 5'-AAAGGCTAA ACACGAAGAAACTGT- $3^{\prime}$ and pmHMGR: 5'-TTGTAACGGTA ACCAGGATTTTC-3'. Multiplex PCR was carried out in a $10-\mu l$ volume containing $1 \mu \mathrm{l}$ of $10 \times$ PCR buffer, $1 \mu \mathrm{l}$ of dNTPs, $0.5 \mu \mathrm{l}$ of each of the four primers $(10 \mu \mathrm{M}), 0.07 \mu \mathrm{l}$ of ExTaq (Takara Bio, Inc.), $1 \mu \mathrm{l}$ of DNA template, and $4.93 \mu \mathrm{l}$ of double-distilled water. Thermal cycler conditions were initial denaturation at $95^{\circ} \mathrm{C}$ for $2 \mathrm{~min}$; followed by $95^{\circ} \mathrm{C}$ for $30 \mathrm{~s}, 55^{\circ} \mathrm{C}$ for $30 \mathrm{~s}$, and $72^{\circ} \mathrm{C}$ for

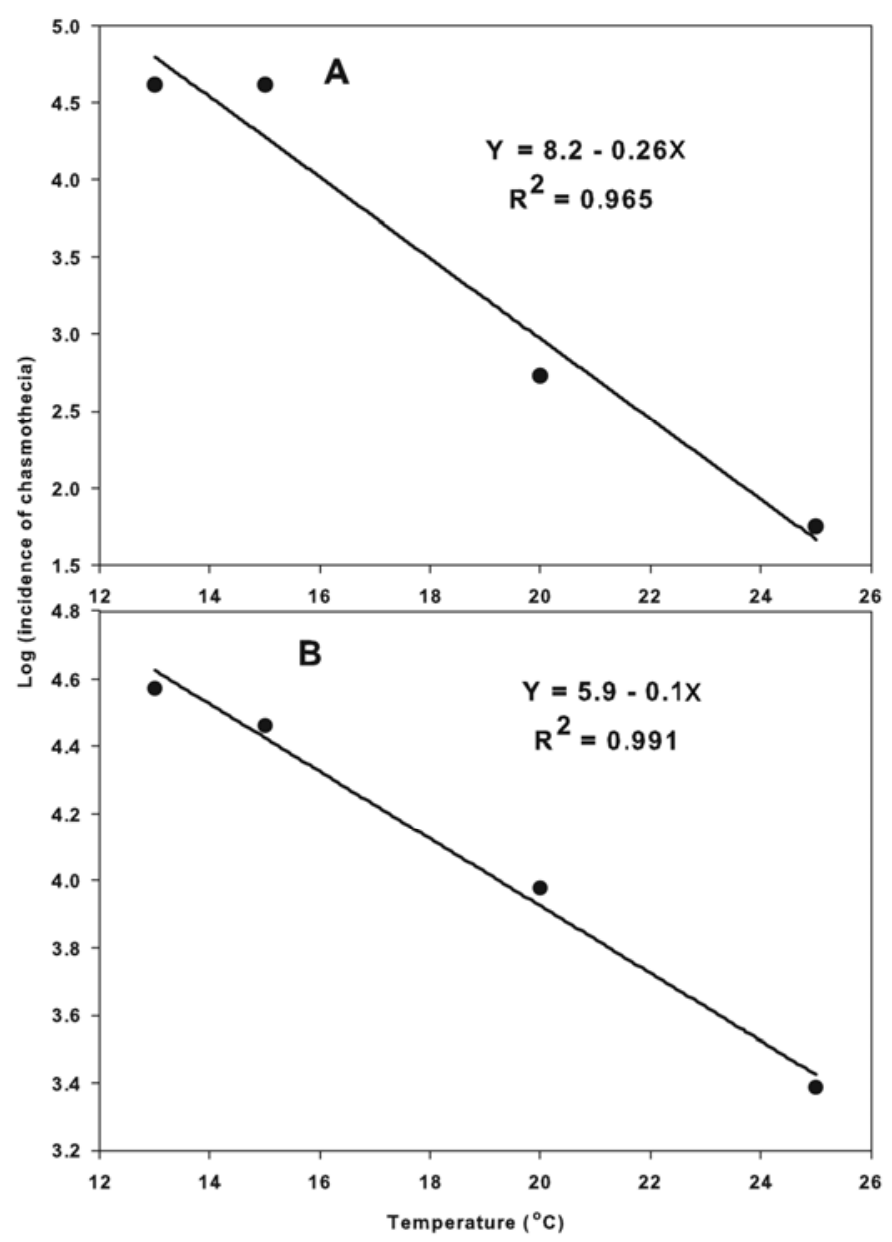

Fig. 2. Relationship between the incidence of strawberry leaves bearing chasmothecia and incubation temperature for compatible isolates A, Sola $\times$ Hamar and B, Sola $\times$ Ringsaker.
$30 \mathrm{~s}$; followed by 35 cycles of $95^{\circ} \mathrm{C}$ for $30 \mathrm{~s}, 55^{\circ} \mathrm{C}$ for $30 \mathrm{~s}$, and $72^{\circ} \mathrm{C}$ for $30 \mathrm{~s}$; followed by a final extension at $72^{\circ} \mathrm{C}$ for $5 \mathrm{~min}$. The PCR products were separated by electrophoresis in a $2 \%$ agarose gel.

Statistical analysis. Data were transformed using $\log (x+1)$ when there was a deviation from the assumption of normal distribution of variances. Significant differences among treatments were determined using analysis of variance (25), followed by Tukey's test when treatments were observed to have significant effect $(P \leq 0.05)$. In the regression analysis, when the residual plot revealed nonrandom pattern of data distribution, the data were transformed by nonlinear transformations (logarithm or square root) to achieve linearity. The transformation method that resulted in the highest coefficient of determination $\left(R^{2}\right)$ was presented.

\section{RESULTS}

Compatibility and productivity of isolates. Consistent with the previous results reported by Gadoury et al. (9), additional isolates collected from different locations in Norway produced chasmothecia only when compatible isolates were paired (Table 1). Chasmothecial initials were discernible 10 to 14 days after inoculation when incubated at $13{ }^{\circ} \mathrm{C}$ in all compatible pairings. Chasmothecia formed in 15 of 36 possible isolate pairings, with incidence of leaflets bearing chasmothecia at 28 to $100 \%$ of inoculated leaflets (Table 1). The number of chasmothecia that formed per unit of leaf area also varied significantly $(P=0.001)$ among some pairings (Fig. 1), ranging from 42 to 395 chasmo-

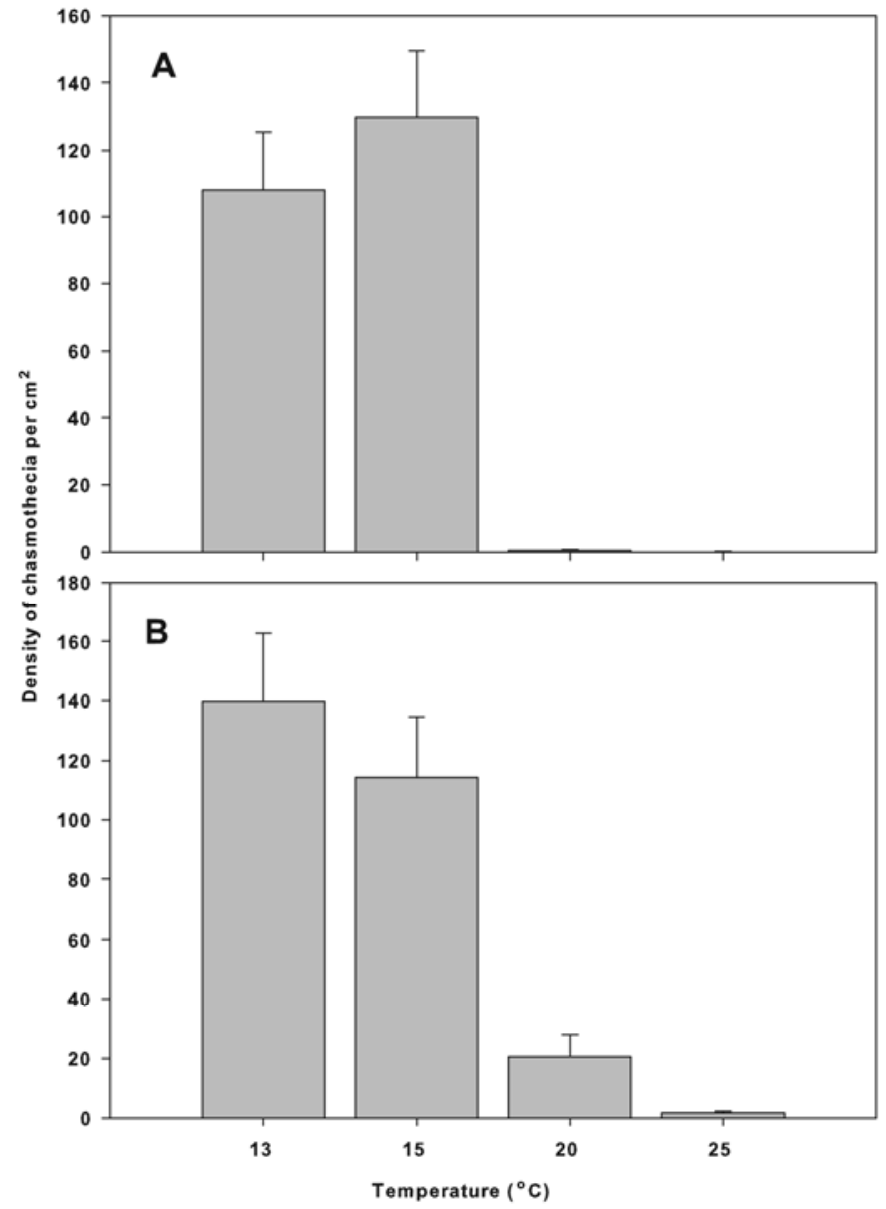

Fig. 3. Reduction in number of chasmothecia produced per square centimeter of infected strawberry leaf area with increase in temperature for isolate pairs A, Sola $\times$ Hamar and B, Sola $\times$ Ringsaker. Error bars denote standard error of the mean. 
thecia/ $\mathrm{cm}^{2}$ (Fig. 1). Pairing of isolates Sola and Hamar and isolates Sola and Ringsaker formed nearly twice as many chasmothecia per unit of leaf area (355 to 395 chasmothecia/ $\mathrm{cm}^{2}$ ) as other sexually compatible pairings (i.e., $\approx 50$ to 190 chasmothecia/ $\mathrm{cm}^{2}$ ) (Fig. 1). Pairing of Ringsaker and Holmestrand formed 255 chasmothecia $/ \mathrm{cm}^{2}$. Therefore, pairings of isolates Sola, Hamar, and Ringsaker were used in further studies on chasmothecia formation.

Influence of temperature on formation of chasmothecia. When compatible isolates were paired, both the incidence of leaves bearing chasmothecia as well as the number of chasmothecia that were initiated per unit of leaf area were inversely proportional to incubation temperature (Figs. 2 and 3). Regression of the incidence of leaves bearing chasmothecia against the temperature yielded the following equations: $Y=8.2-0.26 X$, $R^{2}=0.965$ for isolate pair Sola $\times$ Hamar (Fig. 2A), and $Y=5.9-$ $0.1 X, R^{2}=0.991$ for isolate pair Sola $\times$ Ringsaker (Fig. 2B), where $Y=$ natural logarithm of incidence of leaves bearing chasmothecia at 21 days after inoculation and $X=$ temperature $\left({ }^{\circ} \mathrm{C}\right)$. The slope coefficients for Sola $\times$ Hamar and Sola $\times$ Ringsaker were significant at $P=0.02$ and 0.005 , respectively. At 20 and $25^{\circ} \mathrm{C}$, the mean number of chasmothecia per square centimeter was 0 to 21 (Fig. 3) whereas, at 13 and $15^{\circ} \mathrm{C}$, the number was 108 to 140 for both isolate pairs (Figs. 3 and 4B). A similar trend toward significant suppression at higher temperatures $(P=0.001)$ was observed on naturally infected whole plants grown in phytotrons at $9,12,15$, or $18^{\circ} \mathrm{C}$, wherein the incidence of leaves bearing chasmothecia was $92 \%$ (standard error $[\mathrm{SE}]=5.7$ ), $83 \%$ $(\mathrm{SE}=6.9), 7 \%(\mathrm{SE}=4.6)$, and 6\% $(\mathrm{SE}=4.2)$, respectively. Although the number of chasmothecial initials that formed was greatly reduced at higher incubation temperatures (Figs. 3 and 4), the rate of change in chasmothecial coloration from white to brown to black was faster at a higher temperature than at a lower temperature (data not shown).
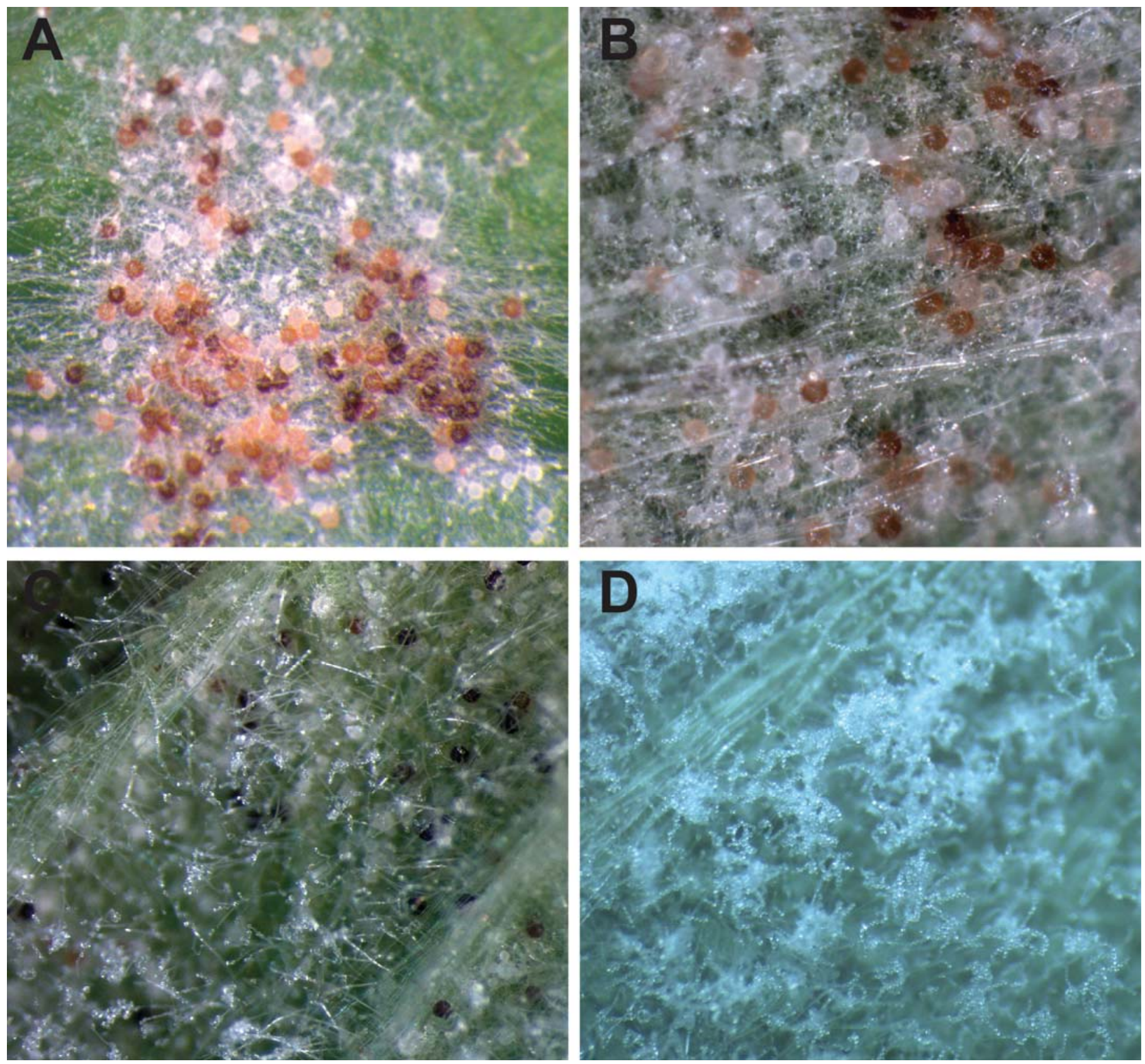

Fig. 4. Production of chasmothecia and conidia by Podosphaera aphanis on strawberry leaves at different temperatures. A, Leaf of a naturally infected whole plant that was incubated at $12^{\circ} \mathrm{C}$. B, Detached leaflet inoculated with compatible isolates and incubated for 3 weeks at $13^{\circ} \mathrm{C} ; \mathbf{C}, 20^{\circ} \mathrm{C}$ isolate $($ Sola $\times$ Ringsaker), and $\mathbf{D}$, $25^{\circ} \mathrm{C}$. Pictures are cropped in the area of a leaflet where the maximum chasmothecial density is observed. 
Duration of low-temperature exposure. The number of chasmothecia initiated increased with increasing hours of incubation at $13^{\circ} \mathrm{C}$. At 14 days after inoculation, the mean number of chasmothecia formed per square centimeter of leaf was 11.9 $(\mathrm{SE}=1.9), 27.1(\mathrm{SE}=2.6), 70.2(\mathrm{SE}=5.5)$, and $155.5(\mathrm{SE}=$ 10.4) when leaves incubated at $25^{\circ} \mathrm{C}$ were exposed to $0,1,4$, or $24 \mathrm{~h}$, respectively, at $13^{\circ} \mathrm{C}$ per 24 -h cycle. Regression of the number of chasmothecia formed per square centimeter against the square root of the number of hours at $13^{\circ} \mathrm{C}$ per 24 -h cycle yielded the following equation: $Y=6.3+30.3 X, R^{2}=0.989$, where $Y=$ the number of chasmothecia per square centimeter 14 days after inoculation and $X=$ the square root of the number of hours of incubation at $13^{\circ} \mathrm{C}$ per $24-\mathrm{h}$ cycle, with incubation temperature at $25^{\circ} \mathrm{C}$ during the balance of the 24-h cycle (Fig. 5). The slope coefficient was significant at $P=0.005$. The relatively low numbers of chasmothecia formed at $25^{\circ} \mathrm{C}$ was not due to lack of pathogen growth, because paired isolates sporulated profusely when incubated at $25^{\circ} \mathrm{C}$ (Fig. 4D).

Both light microscopy and SEM observations of selected chasmothecia indicated that the developmental sequence of chasmothecia maturation was not affected by incubation temperature. The initiation of chasmothecia formation began when the antheridium and ascogonium were formed from the mycelium of the compatible isolates (Fig. 6A and B). Once chasmothecia had reached $\approx 50 \%$ of their mature diameter, myceloid appendages extended outward from cells of the outer chasmothecia wall. The appendages were largely directed downward toward the mildew colony, and appeared to become enmeshed with pannose mycelium of the mildew colony on the leaf surface (Fig. 6C and D).

Conidiation in paired and unpaired isolates. The number of conidiophores bearing conidia was significantly $(P=0.001)$ reduced in areas of leaves bearing chasmothecia when isolates were paired compared with the conidiophore production among the same isolates grown singly (Fig. 7). The reduction in conidiophore production was evident by 16 days after inoculation. However, total conidia production per leaf was not affected by paring of sexually compatible isolates (Fig. 8). This was evident when the initial crop of conidia was removed by washing and assessed at 14 days after inoculation (Fig. 8), or when resporulation was assessed 16 or 20 days after inoculation (Fig. 8). The reduction in asexual reproduction appeared to be restricted to those areas of the colony actively producing chasmothecia.

Mating-type phenotype and genotype. Pairings of clonal isolates indicated the presence of two mutually exclusive mating

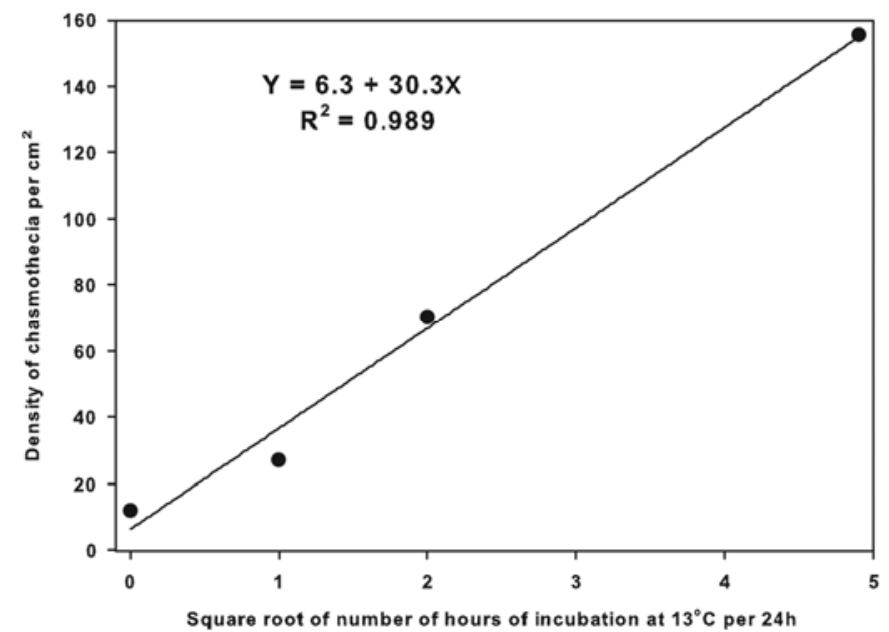

Fig. 5. Regression of the number of chasmothecia per square centimeter strawberry leaf area against the number of hours of incubation at $13^{\circ} \mathrm{C}$ for 24 , 4,1 , or $0 \mathrm{~h}$ per 24 -h cycle, where $Y$ is number of chasmothecia per square centimeter and $X$ is square root number of hours of incubation at $13^{\circ} \mathrm{C}$ per 24-h cycle.

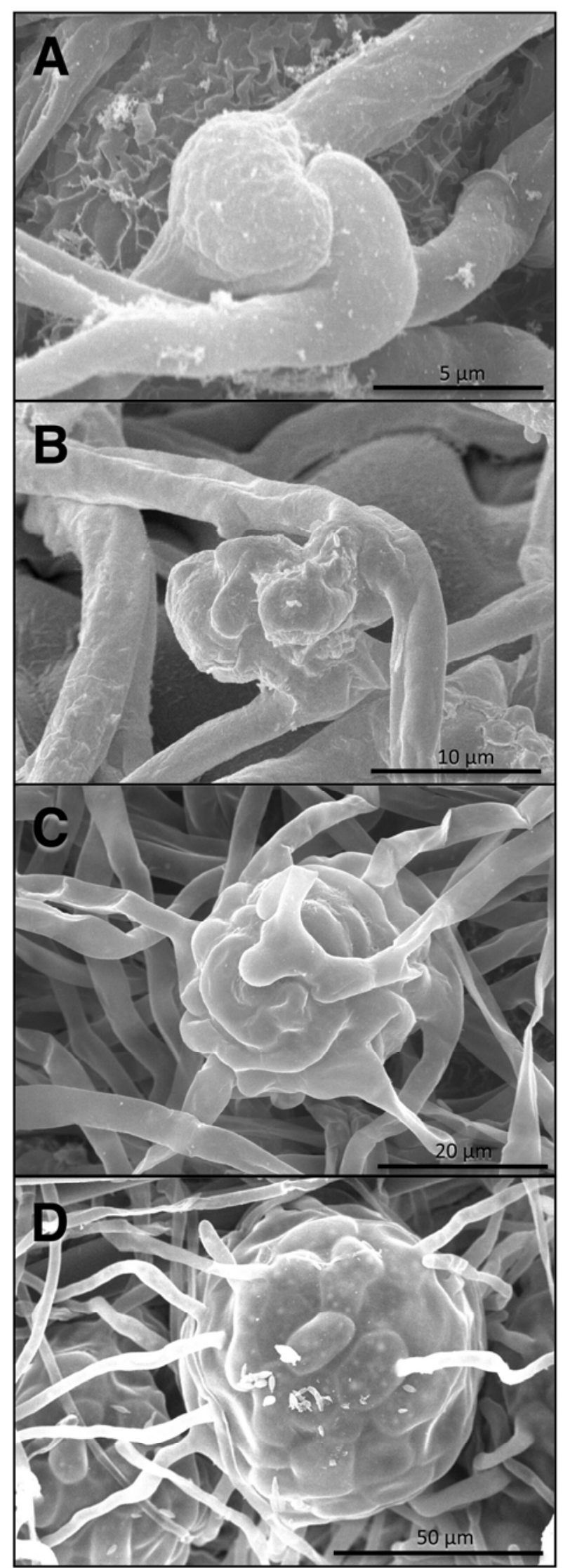

Fig. 6. Developmental stages of chasmothecia in Podosphaera aphanis. A, Initial coiling of antheridium and ascogonium following contact of hyphae of compatible mating types; $\mathbf{B}$, fusion of antheridium and ascogonium to form ascocarp initial; $\mathbf{C}$, early formation of hyphal outgrowths from the ascocarp wall; and $\mathbf{D}$, enmeshment of the hyphal outgrowths in the pannose mycelium of the mildew colony as the chasmothecium reached its mature diameter. 
types in New York, consistent with the results in Table 1. Based on the pairing results, we assigned the isolates $\mathrm{A}, \mathrm{B}, \mathrm{E}$, and $\mathrm{F}$ as "+" type and isolates C and G as "-" type (Fig. 9). Primers specific to the $\alpha$-box region of MATl-1 and the HMG domain region of MAT1-2 produced a 125-bp fragment in "-_" isolates and a 228-bp fragment in "+" isolates. Based on expected sizes of the fragments, this indicated that "+"-type isolates (A, B, E, and F) were MAT1-2 and "-"-type isolates (C and G) were MAT1-1 (Fig. 9). The phenotype and genotype results correlated (Fig. 9).

\section{DISCUSSION}

Chasmothecia of $P$. aphanis are thought to be uncommon in many strawberry-growing regions, particularly in those with relatively warm climates. Indeed, discovery of chasmothecia in Florida in 1981 was sufficiently novel to merit publication (14). Our earlier report (9) and present confirmation of the heterothallic nature of populations, together with our finding that relatively higher temperatures suppress chasmothecia initiation, may provide an explanation for the temporal and geographic discontinuity for the distribution of chasmothecia in this pathosystem. Previous work on other heterothallic powdery mildews has demonstrated that disease must build to a critical level or persist for a critical period of time before the chance pairing of compatible isolates becomes likely on susceptible host tissue $(10,30)$. The requirement for a period of pathogen spread and growth and the consequent occurrence of compatible mating types in close proximity on the same tissue would be essential to initial mate recognition and cell-to-cell fusion leading to chasmothecium initiation $(8,22)$. With respect to temperature, Jackson and Wheeler (15) similarly found no chasmothecia of P. mors-uvae (Schwein.) U. Braun \& S. Takam. at $20^{\circ} \mathrm{C}$ on blackcurrant. Peries (28) was unable to produce chasmothecia of $P$. aphanis by pairing isolates on strawberry leaves at $20^{\circ} \mathrm{C}$ and suggested that $P$. aphanis was not heterothallic. Jhooty and McKeen (16) found chasmothecia in October on the lower surfaces of strawberry leaves in Canada, and Khan (21) found chasmothecia in early May on plants kept in an unheated glasshouse in the United Kingdom. Our results suggest that formation of chasmothecia by $P$. aphanis may not only require a substantial buildup of foliar disease and, thereby, the presence of compatible mating types on the same tissue, but this critical event also must coincide with relatively cooler temperatures conducive to chasmothecia initiation.

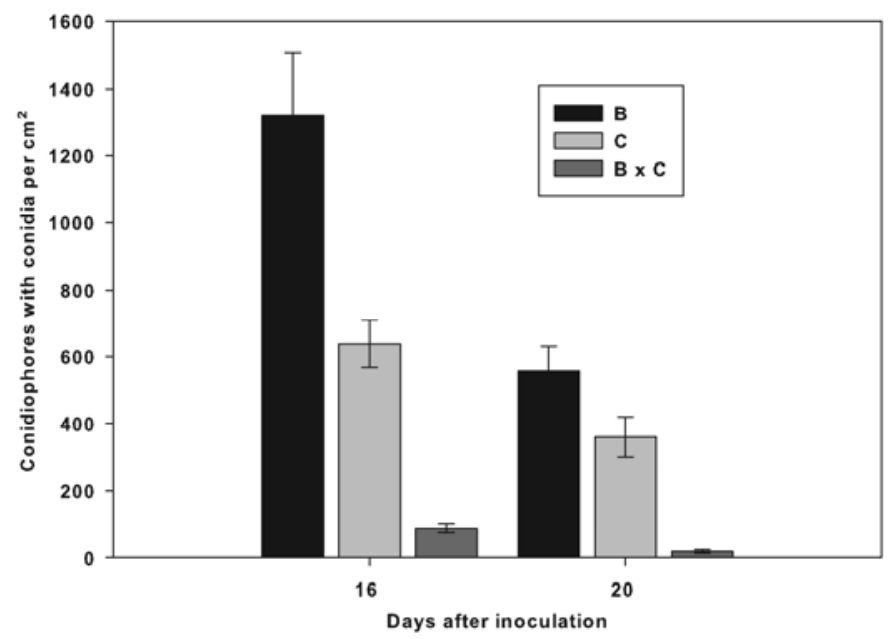

Fig. 7. Conidiophores of Podosphaera aphanis bearing conidia from paired and unpaired isolates 16 and 20 days after inoculation. Conidiophores bearing newly formed conidia were counted at $\times 35$ magnification near the point of initial inoculation for New York isolates B and C grown as separate colonies or as paired isolates on the same leaf.
The requirement for a substantial number of hours per day at $13^{\circ} \mathrm{C}$ temperatures to maximize the initiation of chasmothecia, together with heterothallism, may also explain several noncausal associations of chasmothecia of $P$. aphanis with other factors reported elsewhere. Jhooty and McKeen (16) proposed that the physiological changes in the host, senescence, or changes in photoperiod during the autumn may have induced $P$. aphanis to produce chasmothecia. However, we found chasmothecia on young leaves and runners on plants exposed to low temperature in the phytotron without signs of leaf senescence or starvation of the host, and with no change in photoperiod.

Initiation and development of chasmothecia by $P$. aphanis reduced the production of conidia but did not completely stop it. This contrasts with the near cessation of conidiation throughout a colony in E. necator once mating occurs (12). When compatible isolates were paired at $13^{\circ} \mathrm{C}$, the principal reduction in conidiation occurred in those areas of the colony that were directly supporting the developing chasmothecia, whereas conidiophores in more distant parts of the mildew colony that were devoid of chasmothecia continued to produce conidia (Fig. 8). The optimum temperature for chasmothecium formation by P. aphanis was 5 to $7^{\circ} \mathrm{C}$ lower than the optimum temperature for conidia production. Nonetheless, conidiation was abundant in both paired and unpaired isolates at $13^{\circ} \mathrm{C}$ apart from those areas of the colony that bore developing chasmothecia in the paired isolates (Fig. 8). The reduction in the conidia yield after removal of the initial conidia in the paired compared with unpaired isolates at 16 and 20 days after inoculation may suggest that sporulation did not increase in paired isolates once chasmothecia are formed even if colonies were transferred to temperatures optimal for conidiation $\left(18^{\circ} \mathrm{C}\right)$ (Fig. 8).

In the present study, we identified conserved regions of the mating-type locus in $P$. aphanis and developed a PCR-based marker for the identification of mating type. Use of these markers in our ongoing studies will greatly facilitate the detection of compatible mating types in populations independent of the presence of chasmothecia (8). To date, all heterothallic ascomycetes contain a single mating-type locus, MAT1, with two possible forms or idiomorphs, usually specified as MAT1-1 or MAT1-2 (23). The definitive genes for these idiomorphs encode transcription factors that regulate sexual reproduction (6). In heterothallic ascomy-

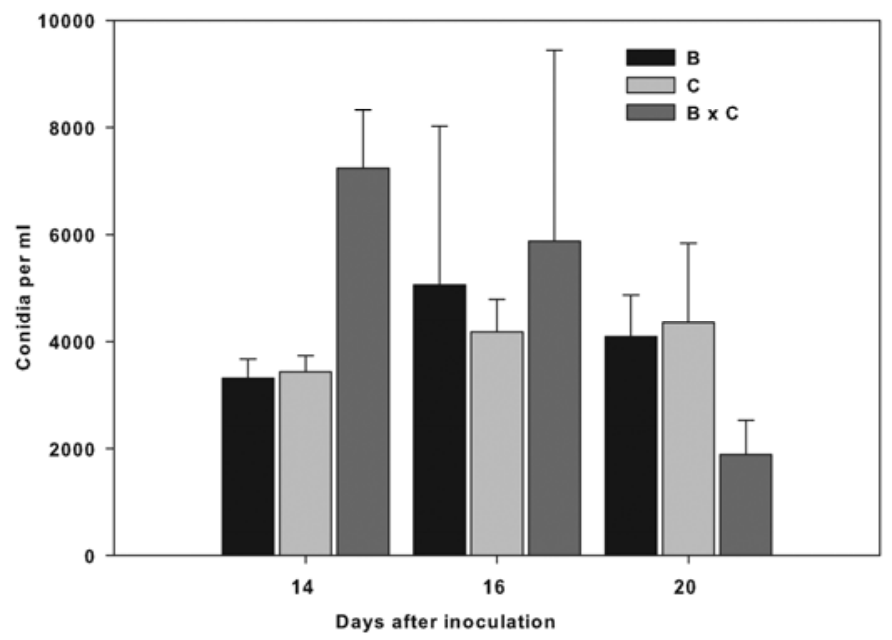

Fig. 8. Effect of chasmothecia formation by Podosphaera aphanis on production of conidia on detached strawberry leaflets. Leaflets were inoculated with New York isolates B and C grown as separate colonies and as paired isolates on the same tissue. Conidia were removed by washing the leaflets in $20 \mathrm{ml}$ of sterile water 14 days after inoculation and were counted in a 5- $\mu \mathrm{l}$ suspension for each treatment. After conidial counts, the leaflets containing the mycelium were incubated at $18^{\circ} \mathrm{C}$ and reassessed for formation of conidia. Error bars denote one standard error of the mean. 

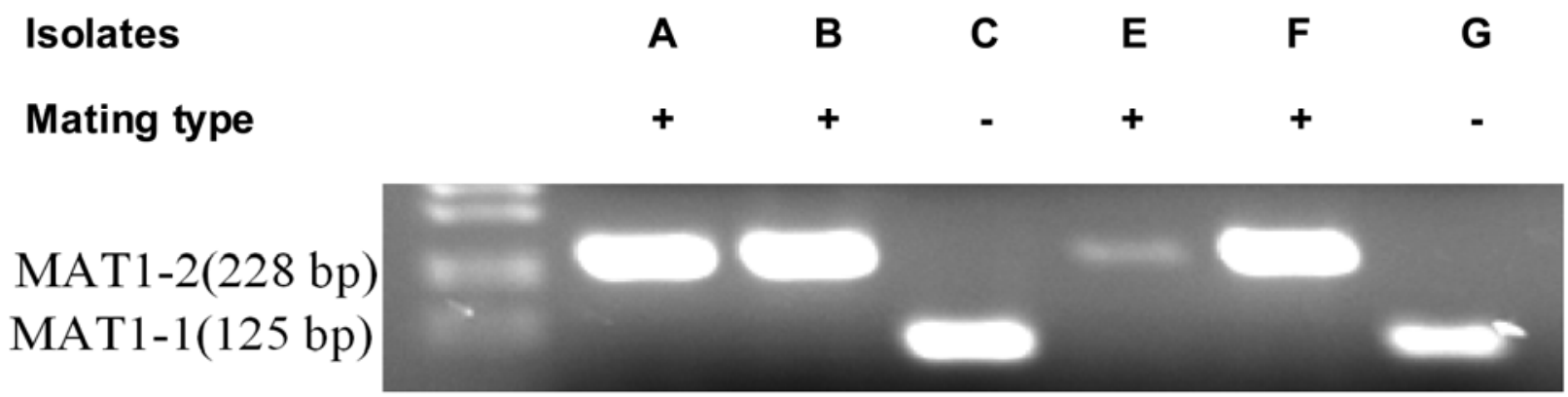

Fig. 9. Correspondence between mating-type phenotype (after crossing isolates) and genotype of Podosphaera aphanis isolates collected in New York. Isolates followed by the same sign had identical mating types based on chasmothecia formation (A, B, E, and F were "+" and C and G were "-"). Mating-type was confirmed based on amplicon size, with isolates A, B, E, and F being MAT1-2 (228 bp) and C and G being MAT1-1 (125 bp).

cetes, including $P$. aphanis, mating only occurs between isolates with the MAT1-1 and MAT1-2 idiomorphs. In this study, some pairings of compatible isolates consistently produced fewer chasmothecia per unit of leaf area, and a lower frequency of leaves bearing chasmothecia (Fig. 1), which suggests that low productivity among otherwise compatible isolates might result from genetic factors other than the MAT1 locus.

Knowledge of factors contributing to formation of chasmothecia of $P$. aphanis can affect management of the disease in strawberry production. Ascospores are an important source of primary inoculum (9). Glasshouse and high-tunnel production systems may allow temperatures to be manipulated to preclude chasmothecia initiation. In relatively warm production regions, temperature thresholds may be established to warn of impending production of chasmothecia. Finally, the suppression of overall disease levels may have impacts upon intercrop survival of the pathogen as chasmothecia by keeping disease below levels where the heterothallic pathogen is likely to mate and, thereby, eliminate a source of primary inoculum.

\section{ACKNOWLEDGMENTS}

This work was supported by the Research Council of Norway, the Norwegian University of Life Sciences, and Bioforsk. Additional support for the work was provided through the United States Department of Agriculture Crops at Risk competitive grants program, and the competitive grants program of the North American Strawberry Growers Association. We thank A. Dobson (Bioforsk) and M. J. Welser (Cornell University) for their excellent technical assistance.

\section{LITERATURE CITED}

1. Amsalem, L., Freeman, S., Rav-David, D., Nitzani, Y., Sztejnberg, A., Pertot, I., and Elad, Y. 2006. Effect of climatic factors on powdery mildew caused by Sphaerotheca macularis f. sp. fragariae on strawberry. Eur. J. Plant Pathol. 114:283-292.

2. Asalf, B., Stensvand, A., Gadoury, D. M., Cadle-Davidson, L., Seem, R. C., Peres, N. A., and Tronsmo, A. M. 2012. Temperature functions as a repressor of ascocarp formation in strawberry powdery mildew Podosphaera aphanis. (Abstr.) Phytopathology 102:S4.7.

3. Asalf, B., Trandem, N., Stensvand, A., Wekesa, V. W., de Moraes, G. J., and Klingen, I. 2012. Influence of sulfur, powdery mildew, and the predatory mite Phytoseiulus persimilis on two-spotted spider mite in strawberry. Biol. Control 61:121-127.

4. Brewer, M., and Milgroom, M. 2010. Phylogeography and population structure of the grape powdery mildew fungus, Erysiphe necator, from diverse Vitis species. BMC Evol. Biol. 10:268.

5. Brewer, M. T., Cadle-Davidson, L., Cortesi, P., Spanu, P. D., and Milgroom, M. G. 2011. Identification and structure of the mating-type locus and development of PCR-based markers for mating type in powdery mildew fungi. Fungal Genet. Biol. 48:704-713.

6. Casselton, L. A. 2008. Fungal sex genes-searching for the ancestors. BioEssays 30:711-714.

7. Corke, A. T. K., and Jordan, V. W. L. 1978. Powdery mildews of bush and soft fruits. Pages 347-357 in: The Powdery Mildews. D. M. Spencer, ed. Academic Press, London.

8. Debuchy, R., and Turgeon, B. 2006. Mating-type structure, evolution, and function in Euascomycetes: Growth, differentiation and sexuality. Mycota 1:293-323.

9. Gadoury, D. M., Asalf, B., Heidenreich, M. C., Herrero, M. L., Welser, M. J., Seem, R. C., Tronsmo, A. M., and Stensvand, A. 2010. Initiation, development, and survival of cleistothecia of Podosphaera aphanis and their role in the epidemiology of strawberry powdery mildew. Phytopathology 100:246-251.

10. Gadoury, D. M., and Pearson, R. C. 1988. Initiation, development, dispersal, and survival of cleistothecia of Uncinula necator in New York vineyards. Phytopathology 78:1413-1421.

11. Gadoury, D. M., and Pearson, R. C. 1991. Heterothalism and pathogenic specialization in Uncinula necator. Phytopathology 81:1287-1293.

12. Gadoury, D. M., Wakefield, L. M., Cadle-Davidson, L., Dry, I. B., and Seem, R. C. 2012. Effects of prior vegetative growth, inoculum density, light, and mating on conidiation of Erysiphe necator. Phytopathology 102:65-72

13. Gourley, C. O. 1979. Cleistothecia of Sphaerotheca macularis on strawberry leaves in Nova Scotia. Can. Plant Dis. Surv. 59:80.

14. Howard, C., and Albregts, E. 1982. Cleistothecia of Sphaerotheca macularis on strawberry plants in Florida. Plant Dis. 66:261-262.

15. Jackson, G. V. H., and Wheeler, B. E. J. 1975. Formation of cleistothecia in Sphaerotheca mors-uvae. Trans. Br. Mycol. Soc. 65:491-496.

16. Jhooty, J., and McKeen, W. 1962. The perfect stage of Sphaerotheca macularis on strawberry plants. Plant Dis. Rep. 46:218-219.

17. Jhooty, J., and McKeen, W. 1965. The influence of host leaves on germination of the asexual spores of Sphaerotheca macularis (Wallr. ex. Fr.) Cooke. Can. J. Microbiol. 11:539-545.

18. Jhooty, J. S., and Mckeen, W. E. 1965. Studies on powdery mildew of strawberry caused by Sphaerotheca macularis. Phytopathology 55:281-285.

19. Jørstad, I. 1928. Beretning om Plantesykdommer i land-og hagebruket V. Hagebrukets nyttevekster. Oslo Grøndahl og søns bokktrykkeri C 39. (In Norwegian)

20. Jørstad, I. 1946. Melding om plantesykdommer i land-og hagebruket. Sykdommer på bærvekster. Rev. Appl. Mycol. 24:456. (In Norwegian)

21. Khan, A. R. 1960. The perithecial stage of Sphaerotheca humuli on strawberry. Plant Pathol. 9:18.

22. Kim, H., and Borkovich, K. A. 2006. Pheromones are essential for male fertility and sufficient to direct chemotropic polarized growth of trichogynes during mating in Neurospora crassa. Eukaryot. Cell 5:544554.

23. Lee, J., Lee, T., Lee, Y. W., Yun, S. H., and Turgeon, B. G. 2003. Shifting fungal reproductive mode by manipulation of mating type genes: obligatory heterothallism of Gibberella zeae. Mol. Microbiol. 50:145-152.

24. Maas, J. L. 1998. Compendium of Strawberry Diseases, 2nd ed. American Phytopathological Society Press, St. Paul, MN.

25. Minitab 14 Statistical Software. 2003. Minitab for Windows. Minitab, Inc., State College, PA.

26. Patwardhan, P. G. 1965. Factors affecting the development of the perithecial stage of powdery mildew of Helianthus annuus in India. Mycopathologia 27:253-256.

27. Peries, O. 1961. Overwintering of Sphaerotheca humuli on strawberry plants. Plant Pathol. 10:65-66.

28. Peries, O. 1962. Studies on strawberry mildew, caused by Sphaerotheca macularis (Wallr. ex Fries) Jaczewski. I. Biology of the fungus. Ann. Appl. Biol. 50:211-224.

29. Schnathorst, W. 1965. Environmental relationships in the powdery mildews. Annu. Rev. Phytopathol. 3:343-366.

30. Smith, C. G. 1970. Production of powdery mildew cleistocarps in a controlled environment. Trans. Br. Mycol. Soc. 55:355-365.

31. Walsh, P. S., Metzger, D. A., and Higuchi, R. 1991. Chelex 100 as a medium for simple extraction of DNA for PCR-based typing from forensic material. Biotechniques 10:506. 